Original Article

\title{
Oral glutamine dipeptide or oral glutamine free amino acid reduces burned injury progression in rats
}

\author{
O dipeptídeo de glutamina oral ou aminoácido livre de glutamina oral reduz a \\ progressão da lesão por queimadura em ratos
}

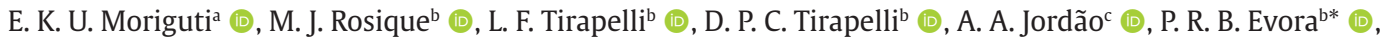 \\ V. F. M. Beldi ${ }^{\mathrm{d}}$ (D) and J. A. Farina Junior ${ }^{\mathrm{a}, \mathrm{b}}$ (D) \\ aUniversidade de São Paulo - USP, Hospital das Clínicas, Unidade de Queimados, Ribeirão Preto, SP, Brasil \\ bUniversidade de São Paulo - USP, Faculdade de Medicina de Ribeirão Preto, Departamento de Cirurgia e Anatomia, Ribeirão Preto, SP, Brasil \\ 'Universidade de São Paulo - USP, Faculdade de Medicina de Ribeirão Preto, Departamento de Ciências da Saúde, Ribeirão Preto, SP, Brasil \\ dUniversidade de São Paulo - USP, Faculdade de Medicina de Ribeirão Preto, Ribeirão Preto, SP, Brasil
}

\begin{abstract}
This study was carried out to evaluate the effect of Glutamine, as a dipeptide or a free amino acid form, on the progression of burn injuries in rats. Thirty male Wistar rats were burned with a comb metal plate heated in boiling water $\left(98^{\circ} \mathrm{C}\right)$ for three minutes, creating four rectangular full-thickness burn areas separated by three unburned interspaces (zone of stasis) in both dorsum sides. The animals were randomized into three groups $(\mathrm{n}=10)$ : saline solution (G1-Control) and treated groups that orally received Glutamine as dipeptide (G2-Dip) or free amino acid (G3-FreeAA). Two and seven days after burn injury, lesions were photographed for unburned interspaces necrosis evolution assessment. Seven days after injury, glutathione seric was measured and histopathological analysis was performed. By photographs, there was a significant reduction in necrosis progression in G3-Free-AA between days two and seven. Histopathological analysis at day 7 showed a significantly higher stasis zone without necrosis and a higher number of fibroblasts in G2-Dip and G3-FreeAA compared with G1-Control. Also, glutathione serum dosage was higher in G2-Dip. The plasmatic glutathione levels were higher in the G2-Dip than the G1-Control, and there was a trend to higher levels in G3-FreeAA. The reduction in histological lesions, greater production of fibroblasts, and greater amounts of glutathione may have benefited the evolution of burn necrosis, which showed greater preservation of interspaces.
\end{abstract}

Keywords: burns, rats, necrosis, glutamine, oxidative stress.

\begin{abstract}
Resumo
Este estudo foi realizado para avaliar o efeito da Glutamina, como um dipeptídeo ou forma de aminoácido livre, na progressão de queimaduras em ratos. Trinta ratos Wistar machos foram queimados com um pente de metal aquecido em água fervente $\left(98^{\circ} \mathrm{C}\right)$ por três minutos, criando quatro áreas retangulares queimadas separadas por três interesespaços não queimados (zona de estase) em ambos os lados do dorso. Os animais foram randomizados em três grupos $(\mathrm{n}=10)$ : solução salina ( $\mathrm{G} 1$-Controle) e grupos tratados que receberam glutamina via oral como dipeptídeo (G2-Dip) ou aminoácido livre (G3-FreeAA). Dois e sete dias após a queimadura, as lesões foram fotografadas para avaliação da evolução da necrose entre os espaços não queimados. Sete dias após a lesão, foi dosada a glutationa sérica e realizada análise histopatológica. Pelas fotografias, houve uma redução significativa na progressão da necrose no G3-Free-AA entre os dias dois e sete. A análise histopatológica no dia 7 mostrou uma zona de estase significativamente maior sem necrose e número mais elevado de fibroblastos em G2-Dip e G3-FreeAA em comparação com G1-Controle. Os níveis plasmáticos de glutationa foram maiores no G2-Dip em relação ao G1-Controle, e houve tendência a níveis mais elevados no G3-FreeAA. A redução das lesões histológicas, maior produção de fibroblastos, maior quantidade de glutationa podem ter beneficiado a evolução da necrose da queimadura, que mostrou maior preservação dos interespaços.
\end{abstract}

Palavras-chave: queimaduras, ratos, necrose, glutamina, estresse oxidativo.

\section{Introduction}

The extent of burn injury is a determining factor for patient survival (Wolfe, 1996) and its depth. Deep burns present higher morbidity and mortality than superficial burns (Farina Junior et al., 2013). Deep burn wound presents a central necrotic zone, surrounded by the stasis zone. The Stasis zone may progress to necrosis, extending areas

*e-mail: prbevora@gmail.com

Received: April 12, 2021 - Accepted: July 9, 2021

This is an Open Access article distributed under the terms of the Creative Commons Attribution License, which permits unrestricted use, distribution, and reproduction in any medium, provided the original work is properly cited. 
requiring surgical treatment. Also, perfusion alterations, inflammation, and oxidative stress may influence burn injury necrosis progression (Singer et al., 2011).

Glutamine plays a significant role in oxidative stress because it is a precursor of Glutathione, a critical non-enzymatic antioxidant (Goswami et al., 2016; Jalilimanesh et al., 2011; Kesici et al., 2015; Souba et al., 1990). Glutathione attenuates nitric oxide synthase (NOS) expression inhibiting nitric oxide biosynthesis (Meininger and Wu, 1997; Houdijk et al., 1998). Glutathione also helps to protect against ischemia and reperfusion injury (Cheung et al., 2000). Exogenous antioxidants supply has been studied to curb or reduce the damage caused by excessive oxidant production (Gürbüz et al.,1997; Sena et al., 2018). The previous study has shown that oral L-glutamine promotes wound healing, acting in collagen synthesis, and improves the cutaneous lesion's wound contraction rate and epithelization (Goswami et al., 2016). One study evaluated oral glutamine $(1 \mathrm{~g} / \mathrm{kg})$ effects in second-degree burn wounds and observed that glutamine accelerated the burn wound healing process in rats (Jalilimanesh et al., 2011).

In the present investigation, the authors sought to study whether glutamine in the form of free amino acid (L-glutamine), being of low solubility and unstable at high temperatures, would be less effective than supplementation in the form of a dipeptide L -alanyl-L-glutamine (AlaGln), because there are still controversies in this issue (Barbosa et al., 2003; Goswami et al., 2016; Rogero, 2004).

The main objective of the present investigation was the evaluation of burn treatment by oral effects of two pharmaceutical presentations (dipeptide or free amino acid). Nevertheless, the observation about the thermal burn method adopted was another reason. The objectives of animal experimentation in the field of burns research have changed considerably in the past decades (Abdullahi et al., 2014). However, the search for experimental methods for burn studies is still a matter of controversy. Thus, the confirmation of its efficiency is a secondary objective.

\section{Methods}

\subsection{Animals}

Male Wistar rats weighing 216-300 g were used in this study. Animals' housing and care were by the Ethical Principles in Animal Research adopted by the National Council for the Control of Animal Experimentation (CONCEA) and approved by the Local Animal Ethical Committee from Ribeirão Preto Medical School of the University of São Paulo (Protocol 44/2014). Animals were kept at a $12 \mathrm{~h}$ light/dark cycle, at room temperature of $22-25^{\circ} \mathrm{C}$, and free access to water and commercial diet for rodents-Nuvilab CR-1, Nuvital Nutrients S/A, Brazil. Every day the animals were weighed as well as the feed intake was noted.

Thirty animals were randomly assigned into three groups ( $\mathrm{n}=10$ ): Saline group (G1-Control) received 7,4 ml/kg body weight (B.W.)/day of saline solution $0,9 \%$; Dipeptide group (G2-Dip) received 7,4 ml/kg B.W./day of dipeptide L-alanyl-L-glutamine (Diamin ${ }^{\circledR}$ Solution), manufactured by Cláris -Produtos Farmacêuticos do Brasil-Ltda and fractionated and supplied by the company Formula Medicinal-Suporte Nutricional e Manipulação Ltda., São Paulo, Brazil, containing $1 \mathrm{~g} / \mathrm{kg}$ B.W./day of L-glutamine and $0,61 \mathrm{~g} / \mathrm{kg}$ B.W./day of L-alanine; and Free amino acid group (G3-Free $A A-n=10$ ) received $1 \mathrm{~g} / \mathrm{kg}$ B.W./day of L-glutamine and $0,61 \mathrm{~g} / \mathrm{kg}$ B.W./day of L-alanine in free forms, was manufactured and provided by Ajinomoto Interamericana Indútria e Comércio Ltda. do Brazil, dissolved in 7,4 ml $/ \mathrm{kg}$ B.W./day of saline solution $0,9 \%$. All three groups received these solutions orally by gastric gavage. Treatments were administered to all animals two hours after burn injury and then daily in the morning, until the day of euthanasia with anesthetic overdose (day 7).

\subsection{Experimental protocol}

The rats were weighed and then anesthetized with ketamine (50mg/kg) (Cetamin, Syntec, Brazil) and xylazine $(10 \mathrm{mg} / \mathrm{kg}$ ) (Dopaser, Hertape Calier, Brazil) by peritoneal injection. Animals' back was shaved with electric clippers (Oster Golden A5, USA) and depilated with Veet (Reckitt Benckiser, Brazil).

The comb burn model was used to create full-thickness thermal injury (Regas and Ehrlich, 1992). The temperature was standard for all animals. The metal comb was heated in boiling water $\left(98^{\circ} \mathrm{C}\right)$ for three minutes. It was applied perpendicularly to the skin's surface on the back of animals for 30 seconds without pressure, except the weight of the comb, to create four rectangular $10 \times 20 \mathrm{~mm}$ full-thickness burned areas separated by three $5 \times 20 \mathrm{~mm}$ unburned interspaces (zone of ischemia or stasis). This thermal injury model was created on both backsides. No dressing was applied (Figure 1). The animals were also observed at two and seven days after thermal injury.

\subsection{Photographic analysis}

The wounds were photographed with a Canon camera model EOS Kiss X7-Japan. At the time of the photo, a ruler was placed on the animal's side to standardize the area unit in centimeters, to determine the necrosis zone (clotting) in the interspaces (unburned spaces), two and seven days after the injury. To determine the area of necrosis, Image J 1.46 software was used (U.S. National Institute of Health, Bethesda, Maryland, USA, 1997-2012).

\subsection{Histopathological analysis}

All animals were sacrificed seven days after injury. All skin lesions, including burned area and interspaces, were removed, immersed in a $10 \%$ paraformaldehyde fixative solution in $0.1 \mathrm{M}$ phosphate buffer, $\mathrm{pH} 7.3$ at room temperature. After fixation, the samples were submitted to dehydration in a progressive battery of xylol and xylol alcohol and, finally, the inclusion was performed in molten paraffin, kept at room temperature for 24 hours. The material was cut at 5 micrometers in a microtome (Reichert Jung 2040) and stained by Masson's Trichrome technique (evaluation of necrosis, edema, and hemorrhagic foci). The slides were analyzed using a Zeiss ${ }^{\circledR}$ microscope (model Axioskop 2 plus), at 50 and 400 times magnification. The images of the fields used in the histological study 


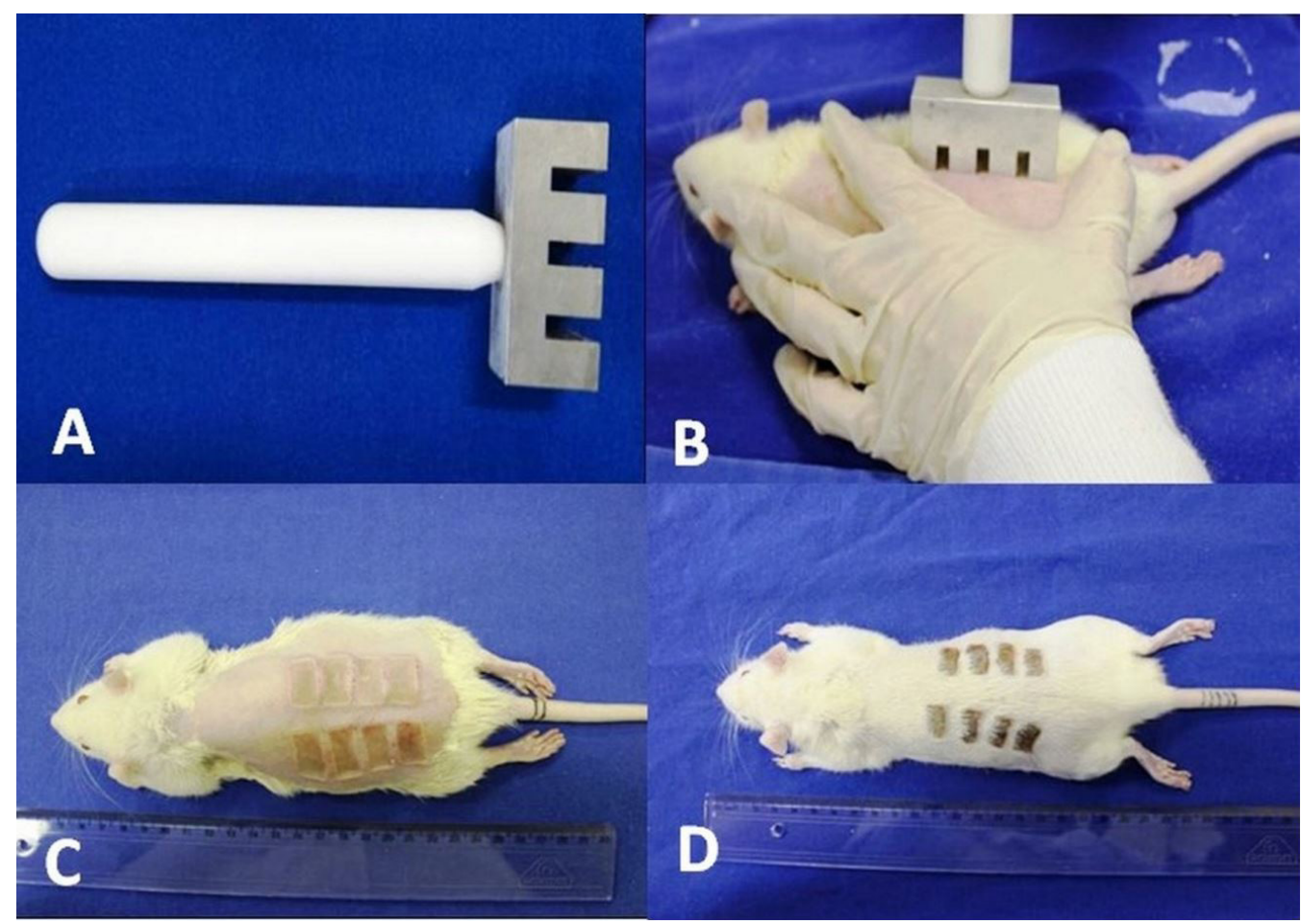

Figure 1. Rat comb burn model: (A) Comb metal plate; (B) Comb burn injury, with four rectangular full-thickness burn areas separated by three unburned interspaces (stasis zone); (C) rectangular burned full thickness areas just after the injury; (D) animal from treated group 7 days after injury showing interspaces (stasis zone) without necrosis.

were recorded by the camera (Axion Cam Scr®) coupled to the microscope and subsequently archived by the Axio Vision 4.6 program. Histopathological analysis was performed blindly by a pathology specialist.

\subsection{Necrotic zone}

For the evaluation of the four areas of burn injury, cuts of the total thickness (tegument) of the entire extension of the application of the metal comb were obtained. For the histopathological characterization of necrosis, edema, and the presence of hemorrhagic foci, the histological technique of Masson's Trichromic was applied.

\subsection{Morphometric of the stasis zone (interspace)}

In the morphometric evaluation at day seven, the viable tissue in the interspace skin regions (stasis zone) was measured (in millimeters) in each injured area caused by the heated metal comb on both dorsum sides of all animals (50x magnification). The total interspace area obtained the average measure of interspace without necrosis (values of the ten animals per group) divided by the 60 interspace regions measured in each group.

\subsection{Fibroblasts count in the stasis zone}

The fibroblast number was counted under $400 x$ magnification (Masson's Trichrome staining technique) by choice of three fields in the interspace regions, one central and two in the transition with the burned areas the dermis.

\subsection{Glutathione concentration in plasma}

The animals' blood was collected seven days after injury, centrifugated at $3000 \mathrm{rpm}$ for 15 minutes, and the plasma was separated and stored at $-80^{\circ} \mathrm{C}$. Glutathione dosage was performed according to Ellman's technique (Davies et al., 1984).

The Sulfhydryl group's concentration was calculated using a standard curve of reduced Glutathione in the unit in mmol/L. For the analysis, a COBAS MIRA Plus ${ }^{\circledR}$ automatic biochemical analyzer(Costa et al., 2006) was used.

\subsection{Statistical analysis}

The comparisons among groups regarding the variables initial weight, weight gain, feed intake, and Glutathione (GSH) were made through analysis of variance (ANOVA). Tukey's post-test for multiple comparisons Montgomery DC, 2012 was also used. For the comparisons among groups regarding necrosis percentage (\%), necrosis range change, morphometric and fibroblasts count, the linear regression model with mixed effects (random and fixed effects) was used. The analysis of the variables initial weight, weight gain and feed intake, comparisons among groups regarding necrosis percentage and necrosis rate change per photograph, morphometric, fibroblasts count, and Glutathione (GSH) were made using software SAS ${ }^{\circledR}$ 
9.2, the USA and all graphs presented were made with the aid Software R, version 3.1.1. For all analyses, a significance $P$ level of less than five percent $(\mathrm{p}<0.05)$ was adopted.

\section{Results}

Animals presented similar weight, weight gain, and feed intake, with no differences among groups $\mathrm{P}>0.05$ ). The authors assume that the animals had normal levels of Glutamine.

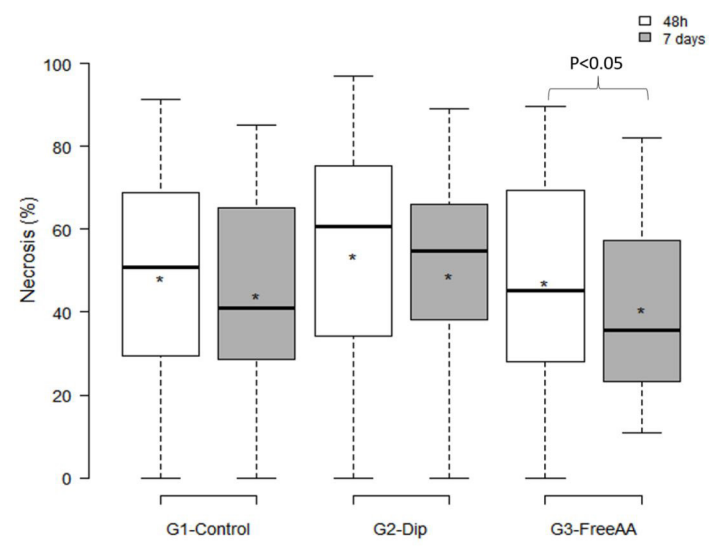

Figure 2. Graphical representation of necrosis percentage evolution obtained by photographic analysis in the burn interspace, two and seven days after injury in G1-Control, G2-Dip and G3-FreeAA. In the G3-FreeAA there was a significant reduction of necrosis between two and seven days * $(\mathrm{P}<0.05)$.

\subsection{Photographic analysis}

Regarding the percentage of necrosis rates of stasis zone, two and seven days after the injury, in G1-Control there was $48.15 \%$ at two days and $44 \%$ at seven days after injury. In G2-Dip, the necrosis percentage after two days was $53.62 \%$ and $48.92 \%$ on day seven. Finally, in G3-FreeAA, at two days, the mean necrosis percentage was $47.07 \%$, and at day seven $40.6 \%$ of the total interspace area. There was no significant difference among groups. However, when necrosis evolution was compared within the same group at two and seven days, there was a significant difference in $\mathrm{G} 3-$ FreeAA $(\mathrm{P}<0,05)$. Therefore, the administration of Glutamine in free amino acid form demonstrated a significant necrosis reduction in the interval between two and seven days. In G1-Control and G2-Dip there was no statistical difference in this time interval (Figure 2)

\subsection{Histopathological analysis}

\subsubsection{Necrotic zone}

The burn areas were confirmed as full thickness in the histological analysis, where the presence of dermis necrosis, hemorrhagic foci, and edema in the dermis and hypodermis and acute inflammatory process were observed (Figure 3).

\subsubsection{Morphometric of stasis zone (interspace)}

In the morphometric evaluation of the unburned interspace regions at day seven, the measures of the amount of viable tissue (without necrosis) was greater in both dorsum sides of the animals of the two groups treated
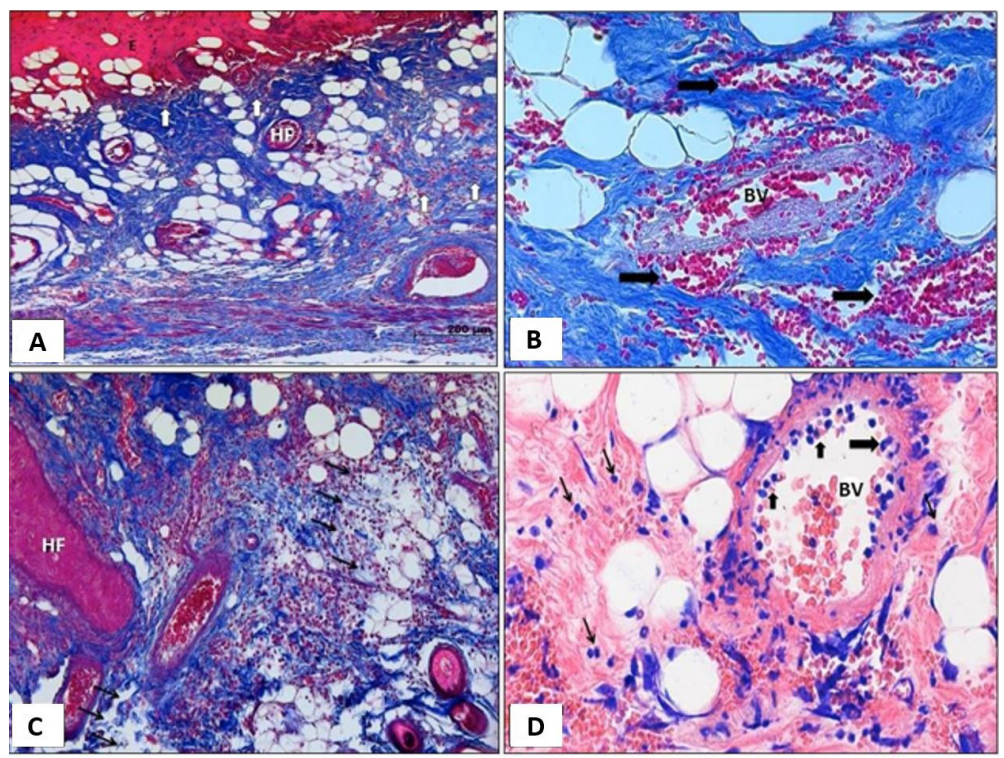

Figure 3. Histopathology study of the necrotic areas: (A) Photomicrograph of G2-Dip animal, with necrosis presence in the dermis (superior arrows) just below the epidermis (E) and in the hypodermis (arrows below in the right). Hair follicle (HF). Masson's trichrome; 100x; (B) Photomicrograph of G1-Control animal, hemorrhagic foci are observed in both dermis and hypodermis (arrows). Central blood vessel (BV). Masson's trichrome; 400x; (C) Photomicrograph of G3-FreeAA animal, with a large area of edema in both dermis and hypodermis (arrows). Hair follicle (HF). Masson's trichrome; 100x; (D) Photomicrograph of G1-Control animal: hemorrhagic focus can be observed in the hypodermis and many neutrophils (minor arrows) in a blood vessel (BV) lumen, some in diapedesis through its wall (larger arrow). The thinner arrows show a small intercellular inflammatory infiltrate. Giemsa; 400x. 
by Glutamine: the G1-Control animals' length measures were $35.6 \mathrm{~mm}$ in total, and the average was $0,593 \mathrm{~mm}$; the G2-Dip animals' length measures (total $39.94 \mathrm{~mm}$ and an average of $0.666 \mathrm{~mm}$ ) were greater than G1-Control measures ( $P<0.01$ ), and the G3-FreeAA animals' length measures (total $39.58 \mathrm{~mm}$ and an average of 0.659) were also greater than $\mathrm{G} 1$-Control measures $(\mathrm{P}<0.01)$ (Figure 4 ).

\subsubsection{Fibroblast quantification in the stasis zone}

The average count of fibroblast in the three fields chosen in the dermis of interspace regions of both dorsum sides of the animals was 41.28 in G1-Control, 46.71 in G2-Dip, and 44.93 in G3-FreeAA groups. Both treated groups had a significantly greater number of fibroblasts than G1-Control $(\mathrm{P}<0.01)$ (Figure 5).

\section{Plasmatic Glutathione}

In plasmatic glutathione evaluation at day seven, G2-Dip animals (average $=11.74 \mu \mathrm{M}$ ) presented higher amount in relation to G1-Control animals (average $=8.829 \mu \mathrm{M}$ ) $(\mathrm{p}<0.05)$ and no difference was observed between G1Control x G3-FreeAA (average $=9.73 \mu \mathrm{M})(\mathrm{P}>0.05)$ and G2-Dip x G3-FreeAA (P > 0.05) (Figure 6).

\section{Discussion}

The main observations of the present investigation were: 1) In the photographs, there was a significant reduction in necrosis progression in G3- Free-AA between days two and seven; 2) The morphometric evaluation at day seven showed larger viable interspaces (less necrosis) in

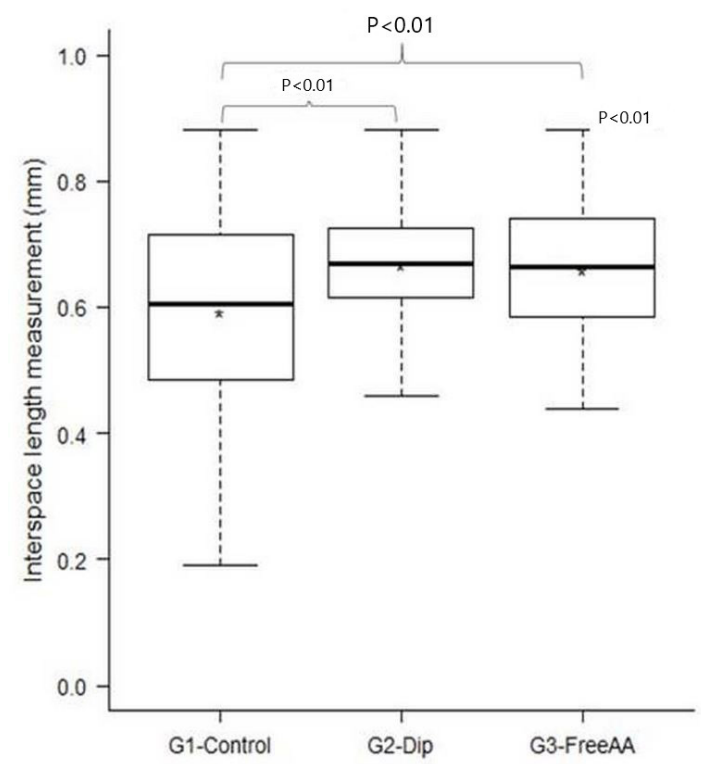

Figure 4. Graphical representation of interspace (stasis) regions length ( $\mathrm{mm}$ ) in the seven days after injury in G1-Control, G2-Dip, and G3-FreeAA. G1-Control presented smaller interspaces in 666 relation to the treated groups G2-Dip $(\mathrm{P}<0.01)$ and G3-FreeAA * $(\mathrm{P}<0.01)$. the stasis zone in G2-Dip and G3-FreeAA compared with G1-Control; 3) The number of fibroblasts in the stasis zone was higher in the treated groups compared to Control, and 4) Glutathione plasmatic dosage at day seven was higher in G2-Dip.

The photograph analysis in the group treated with free amino acid form suggests that this treatment avoided necrosing progression and provided more accelerated healing when compared to the other groups. Improvement in burned wound healing was similarly observed by Jalilimanesh et al. (2011), with benefit from the oral

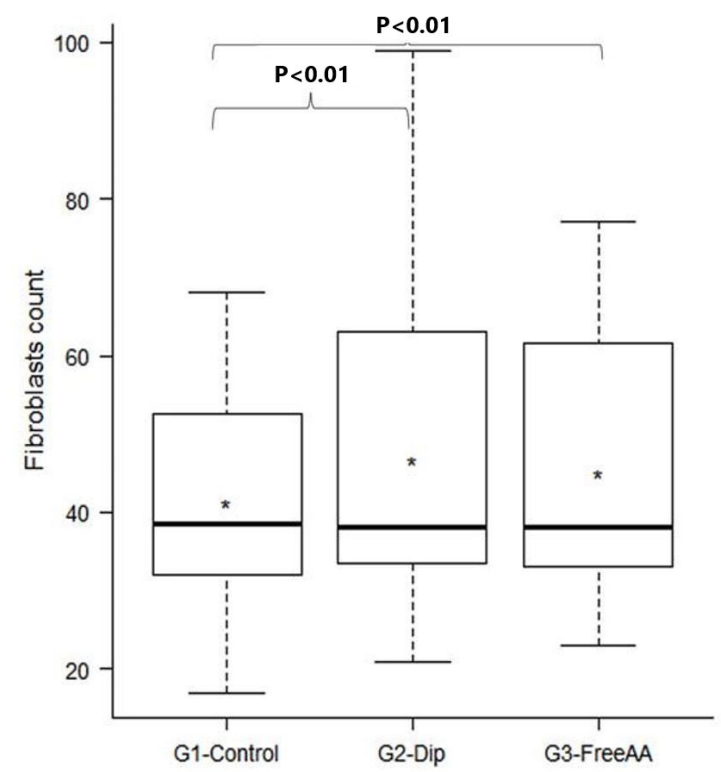

Figure 5. Graphical representation of fibroblast counts in three fields of the interspace dermis among in the seven days after injury in G1-Control, G2-Dip, and G3-FreeAA. G1-Control presented less amount of fibroblast concerning the treated groups G2-Dip $(\mathrm{P}<0.01)$ and G3-Free $A A^{*}(\mathrm{P}<0.01)$.

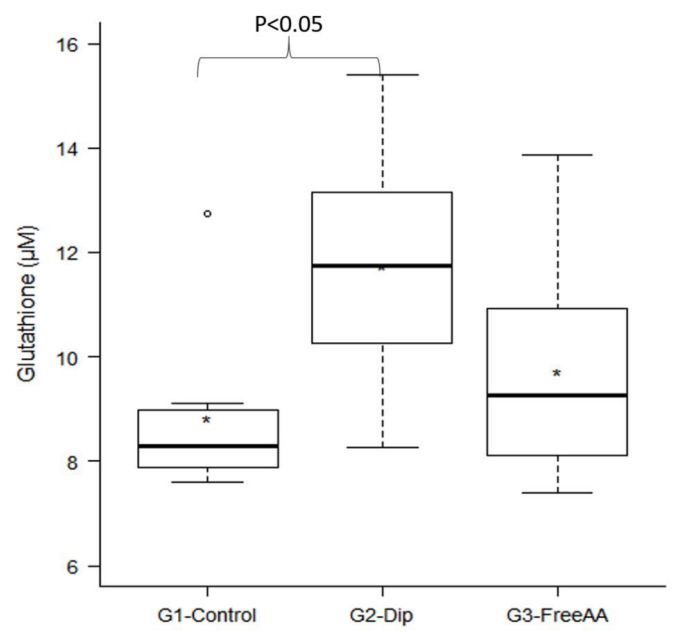

Figure 6. Graphical representation of Glutathione $(\mu \mathrm{M})$ in the seven days after injury in G1-Control, G2-Dip, and G3-Free AA. G2-Dip presented a larger amount concerning the G1-Control ${ }^{*}(\mathrm{P}<0.05)$. 
glutamine administration in the free amino acid form, in the same dosage as used in the present study ( $1 \mathrm{~g} / \mathrm{kg}$ ), in which the treated group obtained a greater wound healing in a shorter time of the lesion in a second-degree burn in rats. Although no significant difference was observed in the group treated with glutamine in dipeptide form (G2Dip) in the photographic evaluation, we observed major preservation of interspace areas in the morphometric analysis, higher number of fibroblasts, and greater levels of glutathione plasmatic dosage in this group.

After a deep burn injury, edema occurs due to vessel dilatation, increased microvascular permeability, and increased extravascular osmotic activity (Demling, 2005; Arturson, 1979). Following these changes, the blood perfusion is impaired, leading to tissue ischemia and necrosis (Zawacki, 1974). It could justify the significant production of ROS (Reactive Oxygen Species), due to the lesion inflammatory systemic reaction (Gürbüz et al., 1997), because the NADPH (Nicotinamide Adenine Dinucleotide Phosphate) oxidase neutrophils are the main ROS cellular producers in the ischemia and reperfusion that occurs in burns (Parihar et al., 2008; Sena et al., 2018). Exaggerated ROS production places all tissues vulnerable to oxidative injury.

Some of our positive results may have been due to glutamine action as a precursor of glutathione, reducing the production of ROS and RNS (Reactive Nitrogen Species) and increasing the expression of the thermal shock protein, since this protein contributes to the survival of cells exposed to various forms of stress. Most studies aimed to increase glutathione concentration have used glutathione precursors, such as $\mathrm{N}$-acetylcysteine or sodium salts of glutathione, based on the assumption that oral reduced glutathione is poorly absorbed and/or oxidized in the gastrointestinal tract (Exner et al., 2000).

In the present study, the use of glutamine provided a greater viable stasis zone (less necrosis) in the treated groups, inferring that glutamine provided stabilization or avoiding the progression of necrosis in the adjacent unburned areas (interspaces).

The more significant number of fibroblasts observed in the glutamine groups may also have contributed to the preservation of the stasis zone. Glutamine is the main source of energy for fibroblasts, which favor the phase of proliferation and remodeling of the healing, synthesizing collagen, and releasing some growth factor that helps epithelization, angiogenesis, and granulation (Chow and Barbul, 2014).

Goswami et al. (2016) also observed a significantly faster wound healing after excision of $500 \mathrm{~mm}^{2}$ on the rats back treated with $1 \mathrm{~g} / \mathrm{kg}$ BW/day of glutamine orally, with a higher number of fibroblasts in the treated group. Differently, Kesici et al. (2015) found no difference in the collagen amount in cutaneous wound healing of a secondary wound by excising $2 \times 1 \mathrm{~cm}$ of skin in rats, offering $0.3 \mathrm{~g} /$ $\mathrm{kg}$ BW/day of glutamine.

In the present study, the group treated with glutamine in the dipeptide form (G2-Dip) had a higher concentration of plasmatic glutathione compared to G1-Control, suggesting that this dipeptide dosage $(1 \mathrm{~g} / \mathrm{kg}$ BW/day of L-glutamine and $0,61 \mathrm{~g} / \mathrm{kg}$ BW/day of L-alanine) worked to allow the conversion from glutamine to glutathione. The organism in a stress-free state maintains the balance between oxidants and antioxidants and ROS scavengers, but when ROS production imbalance occurs, it seems that the amount of antioxidants such as glutathione is not enough to scavenge ROS and RNS (Parihar et al., 2008). It is known that glutamine is a precursor of glutathione, a critical antioxidant.

According to Singer et al. (2011), the zone of stasis in the burn lesion may or may not progress to necrosis and this evolution may be influenced by the change in perfusion, inflammation and oxidative stress induced by ROS. The higher concentration of glutathione found in G2-Dip may have improved the balance of inflammation and oxidative stress that occurs after burns. Glutathione is an important ROS scavenger, that may have enhanced the preservation of the interspaces of the treated groups. Additionally, the higher amount of glutathione found in G2-Dip relative to G3-FreeAA may have occurred because amino acids in the form of dipeptides were transported intact through the intestinal epithelium by PepT-1 (oligopeptides transporter), showing greater absorption for dipeptides compared to the free amino acid (Adibi, 1997).

Finally, we guess we have a good burn experimental model. We already employed it in two other burn investigations about methylene blue intraperitoneal (Rosique et al., 2017) or intradermic (Beldi et al., 2021). So, we can adapt the method as a research line choice.

In clinical practice, glutamine is safe even in high amounts of daily administration (up to $30 \mathrm{~g}$ ) due to its elevated turnover rate, without significant side effects (Roth, 2008). Based on all these data, we suppose that the early administration of glutamine in burn trauma could be useful in reducing the morbidity of progression of necrosis in burned wounds.

Study limitation. The limitation of sample number may have been insufficient to demonstrate a marked difference between treatments. Because it is an animal study, due to anatomical and physiological differences there are limitations in extrapolating to humans. Furthermore, there is still no consensus that glutamine in dipeptide has better efficacy than amino acid form. Since the researches are still controversial (Goswami et al., 2016; Rogero, 2004), so we tested the two forms of Glutamine in this burned rat model.

\section{Conclusion}

In this rodent study, glutamine administration reduced the progression of necrosis in the interval between two and seven days and increased the maintenance of unburned interspace areas (zone of stasis without necrosis), augmented fibroblasts count, and resulted in higher glutathione concentration. All these observations in the groups treated with glutamine may explain the decrease in rats' burn injury progression. Although no difference was observed between the G3-Free AA and the G1-Control groups, there was a trend to higher plasmatic glutathione levels in G3-FreeAA. More studies are necessary, but we suppose that glutamine may be clinically useful in reducing 
the morbidity of progression of necrosis inside the stasis zone if offered in the early phase of burn injury trauma. Eventually, the model of the burns was satisfactory and we can adopt this method as a research line choice.

\section{Acknowledgments}

The authors thank Mayara Piani Luna da Silva Sicchieri and Estela Cristina Carneseca for the statistics job, and the technicians from the Laboratório de Cirurgia Experimental of the Ribeirão Preto Medical School, University of São Paulo (FMRP-USP), Ribeirão Preto, São Paulo, Brazil for the support with the animal procedures.

Glutamine in free amino acid form was manufactured and provided by Ajinomoto Interamericana Industria e Comércio Ltda. and provided by Labsynth Produtos para Laboratórios Ltda.

\section{References}

ABDULLAHI, A., AMINI-NIK, S. and JESCHKE, M.G., 2014. Animal models in burn research. Cellular and Molecular Life Sciences, vol. 71, no. 17, pp. 3241-3255. http://dx.doi.org/10.1007/s00018014-1612-5. PMid:24714880.

ADIBI, S.A., 1997. The oligopeptide transporter (Pept-1) in man intestine: biology and function. Gastroenterology, vol. 113, no. 1, pp. 332-340. http://dx.doi.org/10.1016/S0016-5085(97)701124. PMid:9207295.

ARTURSON, G., 1979. Microvascular permeability to macromolecules in thermal injury. Acta Physiologica Scandinavica. Supplementum, vol. 463, pp. 111-122. PMid:89784.

BARBOSA, R.C.C., GUIMARÃES, S.B., VASCONCELOS, P.R.C., CHAVES, C.R. and VASCONCELOS, P.R.L., 2003. Metabolic effects of glutamine in rats subjected to scald burn. Acta Cirurgica Brasileira, vol. 18, no. 6, pp. 537-541. http://dx.doi.org/10.1590/ S0102-86502003000600008.

BELDI, V.F., ROSIQUE, M.J., TIRAPELLI, L.F., MORIGUTI, E.K., NUNES, A.A., FARINA JUNIOR, J.A. and EVORA, P.R.B., 2021. Intradermal methylene blue administration on the progression of burn injuries. Journal of Wound Care, vol. 30, Sup9a, pp. VIIIi-VIIIx. https://doi.org/10.12968/jowc.2021.30.Sup9a.VIII. PMid: 34570634.

CHEUNG, P.-Y., WANG, W. and SCHULZ, R., 2000. Glutathione protects against myocardial ischemia-reperfusion injury by detoxifying peroxynitrite. Journal of Molecular and Cellular Cardiology, vol. 32 , no. 9, pp. 1669-1678. http://dx.doi.org/10.1006/jmcc.2000.1203. PMid:10966829.

CHOW, O. and BARBUL, A., 2014. Immunonutrition: role in wound healing and tissue regeneration. Advances in Wound Care, vol. 3, no. 1, pp. 46-53. http://dx.doi.org/10.1089/wound.2012.0415. PMid:24761344.

COSTA, C.M., SANTOS, R.C.C. and LIMA, E.S., 2006. A simple automated procedure for thiol measurement in man serum samples. Jornal Brasileiro de Patologia e Medicina Laboratorial, vol. 42, no. 5, pp. 345-350. http://dx.doi.org/10.1590/S167624442006000500006.

DAVIES, M.H., BIRT, D.F. and SCHNELL, R.C., 1984. Direct enzymatic assay for reduced and oxidized glutathione. Journal of Pharmacological Methods, vol. 12, no. 3, pp. 191-194. http:// dx.doi.org/10.1016/0160-5402(84)90059-7. PMid:6536823.
DEMLING, R.H., 2005. The burn edema process: current concepts. The Journal of Burn Care E Rehabilitation, vol. 26, no. 3, pp. 207-227. PMid:15879742.

EXNER, R., WESSNER, B., MANHART, N. and ROTH, E., 2000. Therapeutic potential of glutathione. Wiener Klinische Wochenschrift, vol. 112, no. 14, pp. 610-616. PMid:11008322.

FARINA JUNIOR, J.A., ROSIQUE, M.J. and ROSIQUE, R.G., 2013. Curbing inflammation in burn patients. International Journal of Inflammation, vol. 2013, 715645. http://dx.doi. org/10.1155/2013/715645. PMid:23762773.

GOSWAMI, S., KANDHARE, A., ZANWAR, A.A., HEGDE, M.V., BODHANKAR, S.L., SHINDE, S., DESHMUKH, S. and KHARAT, R., 2016. Oral L-glutamine administration attenuated cutaneous wound healing in Wistar rats. International Wound Journal, vol. 13, no. 1, pp. 116-124. http://dx.doi.org/10.1111/iwj.12246. PMid:24690128.

GÜRBÜZ, V., CORAK, A., YEGEN, B.C., KURTEL, H. and ALICAN, I., 1997. Oxidative organ damage in a rat model of thermal injury: the effect of cyclosporin A. Burns, vol. 23, no. 1, pp. 37-42. http:// dx.doi.org/10.1016/S0305-4179(96)00072-1. PMid:9115608.

HOUDIJK, A.P., VISSER, J.J., RIJNSBURGER, E.R., TEERLINK, T. and VAN LEEUWEN, P.A.M., 1998. Dietary glutamine supplementation reduces plasma nitrate levels in rats. Clinical Nutrition, vol. 17, no. 1, pp. 11-14. http://dx.doi.org/10.1016/S0261-5614(98)80037-X. PMid:10205309.

JALILIMANESH, M., MOZAFFARI-KHOSRAVI, H. and AZHDARI, M., 2011. The effect of oral L-glutamine on the healing of seconddegree burns in mice. Wounds: a Compendium of Clinical Research and Practice, vol. 23, no. 3, pp. 53-58. PMid:25881331.

KESICI, U., KESICI, S., ULUSOY, H., YUCESAN, F., TURKMEN, A.U., BESIR, A. and TUNA, V., 2015. Effects of glutamine on wound healing. International Wound Journal, vol. 12, no. 3, pp. 280-284. http://dx.doi.org/10.1111/iwj.12098. PMid:23738714.

MEININGER, C.J. and WU, G., 1997. L-glutamine inhibits nitric oxide synthesis in bovine venular endothelial cells. The Journal of Pharmacology and Experimental Therapeutics, vol. 281, no. 1, pp. 448-453. PMid:9103529.

PARIHAR, A., PARIHAR, M.S., MILNER, S. and BHAT, S., 2008. Oxidative stress and anti-oxidative mobilization in burn injury. Burns: Journal of the International Society for Burn Injuries, vol. 34, no. 1, pp. 6-17. http://dx.doi.org/10.1016/j.burns.2007.04.009. PMid: 17905515.

REGAS, F.C. and EHRLICH, H.P., 1992. Elucidating the vascular response to burns with a new rat model. The Journal of Trauma, vol.32, no. 5, pp. 557-563. http://dx.doi.org/10.1097/00005373199205000-00004. PMid:1588642.

ROGERO, M.M., 2004. Plasma and tissue glutamine response to acute and chronic supplementation with L-glutamine and L-alanyl-L-glutamine in rats. Nutrition Research, vol. 24, no. 4, pp. 261-270. http://dx.doi.org/10.1016/j.nutres.2003.11.002.

ROSIQUE, M.J., ROSIQUE, R.G., FARIA, F.M., OLIVEIRA, C.C., FARINA JUNIOR, J.A. and ÉVORA, P.R.B., 2017. Methylene blue reduces progression of burn and increases skin survival in an experimental rat model. Burns, vol. 43, no. 8, pp. 1702-1708. http://dx.doi.org/10.1016/j.burns.2017.04.021. PMid:28778756.

ROTH, E., 2008. Non nutritive effects of glutamine. The Journal of Nutrition, vol. 138, no. 10, pp. 2025S-2031S. http://dx.doi. org/10.1093/jn/138.10.2025S. PMid:18806119.

SENA, C.M., LEANDRO, A., AZUL, L., SEIÇA, R. and PERRY, G., 2018. Vascular oxidative stress: impact and therapeutic approaches. Frontiers in Physiology, vol. 9, pp. 1668. http://dx.doi.org/10.3389/ fphys.2018.01668. PMid:30564132. 
SINGER, A.J., TAIRA, B.R., LIN, F., LIM, T., ANDERSON, R., MCCLAIN, S.A. and CLARK, R.A., 2011. Curcumin reduces injury progression in a rat comb burn model. Journal of Burn Care $\mathcal{E}$ Research, vol. 32, no. 1, pp. 135-142. http://dx.doi.org/10.1097/ BCR.0b013e318203337b. PMid:21088615.

SOUBA, W.W., KLIMBERG, V.S., PLUMLEY, D.A., SALLOUM, R.M., FLYNN, T.C., BLAND, K.I. and COPELAND III, E.M., 1990. The role of glutamine in maintaining a healthy gut and supporting the metabolic response to injury and infection. The Journal of
Surgical Research, vol. 48, no. 4, pp. 383-391. http://dx.doi. org/10.1016/0022-4804(90)90080-L. PMid:2187115.

WOLFE, R.R., 1996. Herman Award Lecture, 1996: relation of metabolic studies to clinical nutrition--the example of burn injury. The American Journal of Clinical Nutrition, vol. 64, no. 5, pp. 800-808. http://dx.doi.org/10.1093/ajcn/64.5.800. PMid:8901806.

ZAWACKI, B.E., 1974. The natural history of reversible burn injury. Surgery, Gynecology E' Obstetrics, vol. 139, no. 6, pp. 867-872. PMid:4422280. 